Indo. J. Chem. Res, 2020, 7(2), 107-113

\title{
KAPASITAS ANTIOKSIDAN EKSTRAK BUAH RUKAM (Flacourtia rukam) MENGGUNAKAN METODE MICROWAVE ASSISTED EXTRACTION (MAE)
}

\section{Antioxidant Capacity of Rukam Fruit Extract (Flacourtia rukam) Using Microwave Assisted Extraction (Mae) Method}

\author{
Inas Fadiyah, Iin Lestari, Robby Gus Mahardika* \\ Department of Chemistry, Faculty of Engineering, Universitas Bangka Belitung \\ Gg. IV No. 1, balunijuk, Merawang, Kabupaten Bangka, Kepulauan Bangka Belitung \\ *Corresponding author, e-mail: robbygusmahardika@gmail.com
}

Received: August. 2019 Published: Jan. 2020

\begin{abstract}
Rukam fruit (Flacourtia rukam) is one of the species spread in Indonesia, specifically Bangka Island. Rukam has a higher phenolic ratio than guava (Psidium guajava). Phenolic compounds have a major role as antioxidants, while antioxidants have the ability to fight free radicals. Therefore a study was conducted to examine the application of secondary metabolites and antioxidant bioactivity of the Flacourtia rukam species using the Microwave Assisted Extraction method. Rukam fruit extract is obtained by using the Microwave Assisted Extraction (MAE) method. While for the antioxidant test using the DPPH method. The test results of antioxidant activity of rukam fruit extract with ethanol solvent were obtained with $\mathrm{IC}_{50}$ value $47.7022 \mathrm{ppm}$ and in rukam fruit extract with acetone solvent $\mathrm{IC}_{50} 33.1702 \mathrm{ppm}$ obtained using this antioxidant antioxidant powder was very strong.
\end{abstract}

Keywords: Flacourtia rukam, DPPH, antioxidant activity, Microwave Assisted Extraction.

\section{PENDAHULUAN}

Indonesia merupakan negara agraris yang beriklim tropis sehingga Indonesia memiliki keanekaragaman hayati yang sangat melimpah salah satunya adalah tanaman rukam (Flacourtia rukam) yang merupakan tanaman asal Indonesia. Berdasarkan hasil penelitian sebelumnya menyatakan bahwa buah rukam memiliki kandungan senyawa metabolit sekunder fenolik lebih tinggi dibandingkan dengan jambu batu (Psidium guajava) (Julio dkk., 2018). Senyawa fenolik diketahui sangat berperan pada aktivitas antioksidan, semakin besar kandungan senyawa golongan fenolnya maka semakin besar juga aktivitas antioksidannya (Shahwar dkk., 2010).

Flacourtia rukam merupakan salah satu spesies dari famili Flacourtiaceae yang banyak tersebar di Indonesia khususnya daerah Sumatra seperti pulau Bangka dan cukup mudah ditemui di daerah yang masih alami ditumbuhi hutan. Spesies Flacourtia rukam merupakan salah satu spesies tumbuhan famili Flacourtiaceae memiliki keunikan, yaitu pohonnya berduri dengan tinggi tanaman $7 \mathrm{~m}$, diameter batang $17 \mathrm{~cm}$. Bentuk buah dari spesies Flacourtia rukam bulat kecil berwarna hijau saat muda dan merah saat tua. Belum banyak dilakukan penelitian mengenai Flacourtia rukam, tetapi spesies ini sudah banyak digunakan untuk membuat kue dan selai, daun diaplikasikan untuk mengobati kelopak mata yang meradang, buah digunakan sebagai obat diare dan disentri untuk anak-anak sampai remaja. Sedangkan rebusan akar digunakan oleh wanita setelahnya persalinan (Rana dkk., 2018).

Penelitian tentang kajian metabolit sekunder terhadap Flacourtia rukam belum banyak dilakukan. Penelitian ini melaporkan isolasi kandungan diacylglycerols monogalactosyl (1), $\beta$-sitosteryl $3 \beta$-glucopyranoside-6 $\beta$ - HAI- ester asam lemak (2), betasitosterol (3), triasilgliserol (4), dan klorofil (5) dari Flacourtia rukam (Gambar 1) (Ragasa dkk., 2016). Senyawa 1 adalah non-fosfor lipid paling banyak di alam. Senyawa ini dilaporkan menunjukkan sejumlah sifat biologis, seperti antitumor, anti-virus, algicidal, dan anti-inflamasi (Ragasa dkk., 2015). Senyawa 2 merupakan ester asam lemak mempunyai aktivitas sitotoksisitas terhadap Bowes (melanoma) dan sel kanker MCF7 (payudara). Beta-sitosterol memiliki penghambatan pertumbuhan efek pada payudara 
Inas Fadiyah dkk. / Indo. J. Chem. Res., 2020, 7(2), 107-113

manusia (MCF7) dan sel adenokarsinoma. triasilgliserol memiliki aktivitas antimikroba terhadap $S$. aureus, $P$. aeruginosa, B. subtilis, $C$. albicans, dan T. Mentagrophytes. klorofil dan berbagai turunannya sering digunakan dalam pengobatan tradisional dan untuk tujuan terapeutik. Selain itu Kandungan fenolik menjadi bentuk molekul yang normal kembali serta menghentikan berbagai kerusakan yang dapat ditimbulkan (Mahardika dan Roanisca, 2018). Sekarang ini antioksidan menjadi topik penting dalam berbagai disiplin ilmu (Julio dkk., 2018). Hal ini didasari karena semakin diketahui bahwa sebagian besar penyakit diawali oleh<smiles>[R]C(=O)OCC(COC(C)=O)OC1OCC(O)C(O)C(O)C1O</smiles>

1<smiles>CCC(CC[C@@H](C)[C@H]1CCC2C3CC=C4C[C@@H](O)CC[C@]4(C)[C@H]3CC[C@]21C)C(C)C</smiles>

3

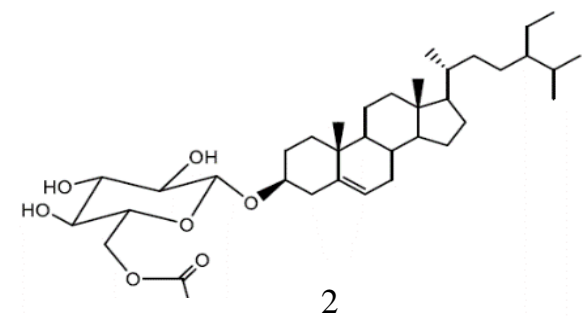

2<smiles>[R]O[C@@H](CO[R]([R])=O)CO[R](=O)[O-]</smiles>

4

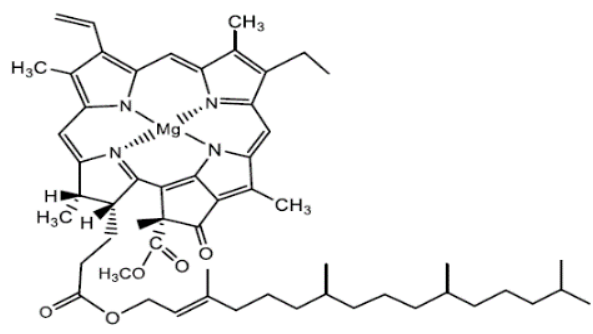

5

Gambar 1. Kandungan Senyawa pada Flacourtia rukam

berkorelasi terhadap aktivitas antioksidan (Ragasa dan Jesus, 2014)

Hal tersebut menunjukkan bahwa buah rukam dapat dimanfaatkan sebagai sumber antioksidan untuk penangkal radikal bebas penyebab berbagai penyakit. Selain itu Flacourtia rukam mengandung metabolit sekunder lainnya yang sangat berguna untuk tujuan pengobatan seperti saponin, flavonoid, polifenol, dan tanin (Barcelo, 2015). Hal ini yang menyebabkan buah rukam dapat digunakan sebagai antioksidan.

Antioksidan merupakan suatu senyawa yang dapat menghambat aktivitas radikal bebas dengan cara kerja menyerahkan satu atau lebih elektronnya kepada radikal bebas sehingga reaksi oksidasi yang berlebihan di dalam tubuh.

Banyak metode yang dapat digunakan untuk mengekstraksi senyawa aktif tumbuhan, biasanya digunakan metode maserasi yang membutuhkan banyak waktu dan tidak efektif (Safdar dkk., 2017). Oleh sebab itu diperlukan pengembangan mengenai metode ekstraksi yang lebih efektif khususnya dari efisiensi waktu dan hasil rendemen yang dihasilkan.

Salah satu pengembangan metode ekstraksi saat ini adalah menggunakan microwave atau yang dikenal dengan istilah Microwave-Assisted Extraction (MAE). Metode ini menggunakan energi yang ditimbulkan oleh gelombang mikro dengan frekuensi $0,30-300 \mathrm{GHz}$ dalam bentuk 
radiasi non-ionisasi elektromagnetik. Keuntungan MAE adalah laju ekstraksi lebih tinggi, konsumsi pelarutnya rendah, dan penggunaan waktu ekstraksi yang lebih signifikan dibandingkan dengan metode maserasi (Hemwimon dkk. 2007). Tetapi tidak semua ekstraksi menggunakan MAE pada setiap tumbuhan menghasilkan antioksidan yang tinggi juga. Senyawa yang termolabil (tidak tahan panas) akan rusak jika diekstraksi menggunakan MAE dengan power dan suhu yang tinggi (Kaufmann dan Christen, 2002). Oleh sebab itu, perlu kajian khusus mengenai ekstraksi senyawa antioksidan dari rukam (Flacourtia rukam) menggunakan MAE.

\section{METODOLOGI}

Alat

Alat-alat yang digunakan adalah blender, Microwave Assisted Extraction (MAE) (Gambar 1), rotary evaporator, corong, botol sampel, hotplate, tabung reaksi, gelas kimia, pipet volum, labu ukur, inkubator, spektrofotometer UV-Vis.

\section{Bahan}

Buah rukam yang diperoleh dari desa Air Duren, Kecamatan Mendo Barat, Kabupaten Bangka (LS -2,085716, BT 106,021224). Bahan kimia yang digunakan adalah metanol, etanol, aseton, akuadestilat, 2,2-diphenil-1picrylhydarzyl (DPPH).

\section{Prosedur Kerja \\ Preparasi Sampel}

Sampel yang digunakan dapat berupa buah yang basah dan kering. Selanjutnya sampel tersebut dijemur dibawah sinar matahari sampai kering. Sampel yang telah kering diblender hingga menjadi serbuk. Kemudian sampel tersebut diayak dengan ayakan mesh 60 untuk mendapatkan bubuk halus. Lalu disimpan ke dalam wadah kedap udara.

\section{Ekstraksi Dengan Mikrowave Assited Extraction (MAE)}

Serbuk kering buah rukam (Flacourtia rukam) diambil sebanyak kurang lebih $0,1 \mathrm{~g}$ dimaskkan $10 \mathrm{ml}$ pelarut dalam tabung mikrowave. Pelarut yang digunakan adalah aseton. Masing-masing pelarut (etanol dan aseton) digunakan 10 tabung mikrowave. Tabung selanjutnya dimasukkan dalam Microwave Accelarated Reaction System (MARS 6) pada suhu $60^{\circ} \mathrm{C}(1200 \mathrm{~W}, 2450 \mathrm{MHz})$ selama 10 menit
(Enggiwanto dkk., 2018). Setelah itu dipisahkan antara filtrat dengan residu menggunakan corong. Filtrat yang diperoleh dievaporasi dengan rotary vacuum evaporator hingga diperoleh ekstrak buah rukam yang pekat.

\section{Uji Aktivitas Antioksidan}

Uji aktivitas antioksidan dilakukan menggunakan metode DPPH yang pengukurannya menggunakan spektrofotometer. Dengan cara Sebanyak $1 \mathrm{~mL}$ larutan sampel dengan konsentrasi $10 ; 30 ; 40$; dan 80 ppm dicampurkan dengan $2 \mathrm{~mL}$ larutan DPPH 0,15 $\mathrm{mM}$. Selanjutnya larutan tersebut dihomogenkan dan didiamkan selama 15 menit pada suhu ruang (sekitar $25^{\circ} \mathrm{C}$ ). Kemudian absorbansinya diukur pada $\lambda$ maks $515 \mathrm{~nm}$ dengan spektrofotometer UV-Vis (Pangestu, 2017). Kemudian masingmasing blanko dan kontrol negatif yang digunakan adalah $2 \mathrm{~mL}$ pereaksi DPPH 0,15 mM. Lalu ditambahkan $1 \mathrm{~mL}$ masing-masing pelarutnya kemudian diukur dengan spektrofotometer UV-Vis.

\section{Analisis Data}

Aktivitas antioksidan pada buah rukam (Flacourtia rukam) dianalisis berdasarkan kekuatan inhibisinya. Kekuatan inhibisinya dihitung menggunakan rumus:

$\%$ Inhibisi $=\left\{\right.$ Abs kontrol $\left.-\left(\frac{\text { Abs sampel }}{\text { Abskontrol }}\right) \times 100 \%\right\}$

Aktivitas peredaman radikal bebas biasanya dinyatakan sebagai presentase peredaman dari DPPH dan dapat juga dinyatakan dengan $\mathrm{IC}_{50}$. Persamaan garis yang diperoleh kemudian digunakan untuk mencari nilai $\mathrm{IC}_{50}$ (konsentrasi yang diperlukan untuk menginhibisi 50\% radikal bebas (Kusbandari dan Prasetyo, 2018).

\section{HASIL DAN PEMBAHASAN}

\section{Ekstrak Buah Rukam}

Ekstraksi buah rukam dilakukan dengan menggunakan metode Microwave Assisted Extraction (MAE) dan maserasi. Microwave yang digunakan adalah MARS 6 dari CEM Corporation (Gambar 2). Pada ekstraksi buah rukam dengan metode MAE diperlakukan sebanyak 1 gram serbuk halus buah rukam ditambahkan $10 \mathrm{ml}$ pelarut pada tabung microwave dengan perbandingan sampel 1: 10 . Pelarut yang digunakan adalah etanol dan aseton. Tabung selanjutnya dimasukkan dalam 
Mikrowave Assisted Extraction (MARS 6) pada suhu $60{ }^{\circ} \mathrm{C}$ dan power sebesar $1200 \mathrm{~W}$ selama 10 menit. Hasil yang diperoleh disaring dan dievaporasi. Rendemen ekstraksi buah rukam disajikan pada Tabel 1 .

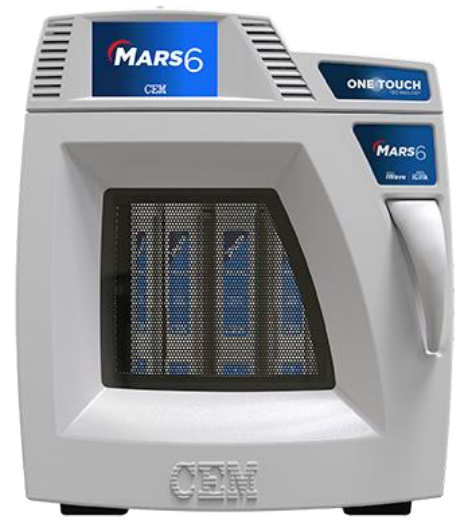

Gambar 2. MARS 6 dari CEM Corporation

Berdasarkan hasil penelitian pada Tabel 1 dapat dilihat bahwa perbedaan penggunaan pelarut yang digunakan dapat mempengaruhi kelarutan senyawa aktif yang akan diekstraksi. Pelarut etanol memilki rendemen hasil ekstraksi yang lebih banyak dibandingkan aseton. Kepolaran senyawa yang terkandung pada buah rukam mempunyai kepolaran yang mendekati kepolaran etanol daripada pelarut aseton, sehingga dapat terekstrak lebih tinggi dengan pelarut etanol (Riza dan Susanti, 2013). Merujuk hasil fitokimia yang telah dilaporkan dari spesies ini, kemungkinan senyawa polar tersebut berupa senyawa alkaloid, fenol hidrokuinon, dan flavonoid (Fadiyah dkk., 2019).

Tabel 1. Hasil Ekstraksi Buah Rukam menggunakan MAE

\begin{tabular}{cccc}
\hline Pelarut & $\begin{array}{c}\text { Suhu } \\
\left({ }^{\circ} \mathrm{C}\right)\end{array}$ & $\begin{array}{c}\text { Waktu } \\
(\text { menit })\end{array}$ & $\begin{array}{c}\text { Rendemen } \\
\text { Hasil } \\
\text { Ekstrak }\end{array}$ \\
\hline Etanol & 60 & 10 & $12,5 \%$ \\
Aseton & 60 & 10 & $7,5 \%$ \\
\hline
\end{tabular}

Jika dibandingkan dengan metode maserasi. Ekstrak etanol buah rukam menggunakan metode maserasi selama 3 hari (pada suhu ruang) didapatkan rendemen sebesar $28,6 \%$, sedangkan jika maserasi menggunakan pelarut aseton didapatkan rendemen sebesar 19,1\% (Fadiyah dkk., 2019). Hasil ini memang 2,3 kali lebih banyak jika dibandingkan hasil ekstraksi menggunakan MAE dengan pelarut yang sama. Tetapi waktu ekstraksi menggunakan maserasi lebih lama 432 kali jika dibandingkan menggunakan MAE. Begitupun juga hasil ekstraksi menggunakan pelarut aseton. Pada metode maserasi selama 3 hari memang memiliki rendemen 2,5 lebih banyak jika dibandingkan menggunakan MAE. Tetapi waktu yang digunakan juga lebih lama. Melihat hasil tersebut, rendemen ekstraksi yang dihasilkan tidak sebanding waktu yang diperlukan untuk ekstraksi. MAE menunjukkan lebih efisien dari segi waktu jika dibandingkan maserasi.

Hal ini diperkuat juga dengan penelitian Hemwimon dkk (2007), ekstraksi antrakuinon dari Morinda citrifolia pada suhu $60^{\circ} \mathrm{C}$ dan waktu yang sama rendemen esktraksi yang dihasilkan jika menggunakan MAE lebih besar dibandingkan menggunakan maserasi (Hemwimon dkk., 2007). Begitupun juga pada ekstraksi senyawa fenolik pada Tristaniopsis merguensis, ekstraksi menggunakan MAE dengan pelarut aseton, etanol, dan metanol memiliki kandungan total fenolik yang lebih tinggi dibandingkan dengan metode maserasi (Mahardika dan Roanisca, 2019).

\section{Uji Aktivitas Antioksidan}

Uji aktivitas antioksidan dilakukan menggunakan metode DPPH. Aktivitas antioksidan diamati dari perubahan warna pada larutan DPPH. Sampel yang telah bercampur dengan pelarut dari warna ungu kehitaman berubah menjadi sedikit lebih terang dari warna awalnya (Gambar 3).

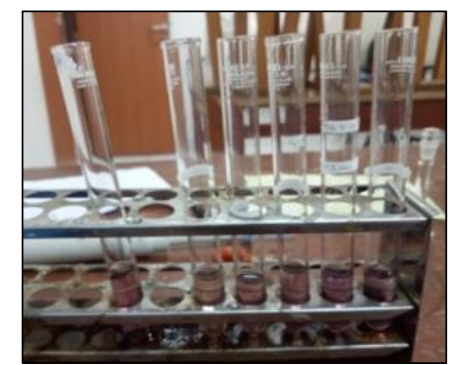

Gambar 3. Uji Aktivitas Antioksidan Metode DPPH

Hasil uji aktivitas antioksidan dengan metode DPPH kemudian diukur menggunakan spektrofotometer pada panjang gelombang maksimum $515 \mathrm{~nm}$. Hasil pengukuran dengan spektroskopi diperoleh nilai absorbansi yang kemudian digunakan untuk memperoleh persentase inhibisi ekstrak buah rukam. 
Inas Fadiyah dkk. / Indo. J. Chem. Res., 2020, 7(2), 107-113

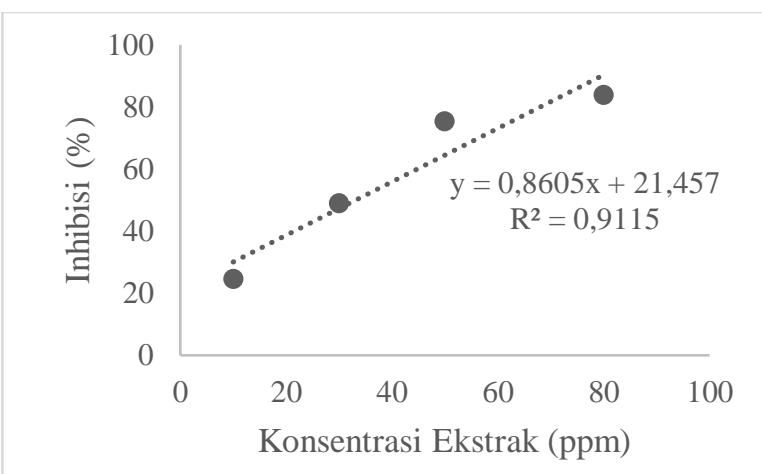

Gambar 4. Nilai Inhibisi Ekstrak Aseton Buah Rukam

Berdasarkan Gambar 4 tersebut diperoleh persamaan regresi linear $y=0,8605 x+21,457$ dan nilai $\mathrm{R}^{2}$ adalah 0,9115 untuk sampel ekstrak aseton buah rukam. Jika nilai $\mathrm{y}=50$ maka didapatkan nila $\mathrm{IC}_{50}$ untuk ekstrak aseton adalah 33,1702 ppm. Nilai inhibisi dan $\mathrm{IC}_{50}$ ekstrak aseton berbeda dengan etanol. Nilai inhibisi ekstrak etanol disajikan pada Gambar 5.

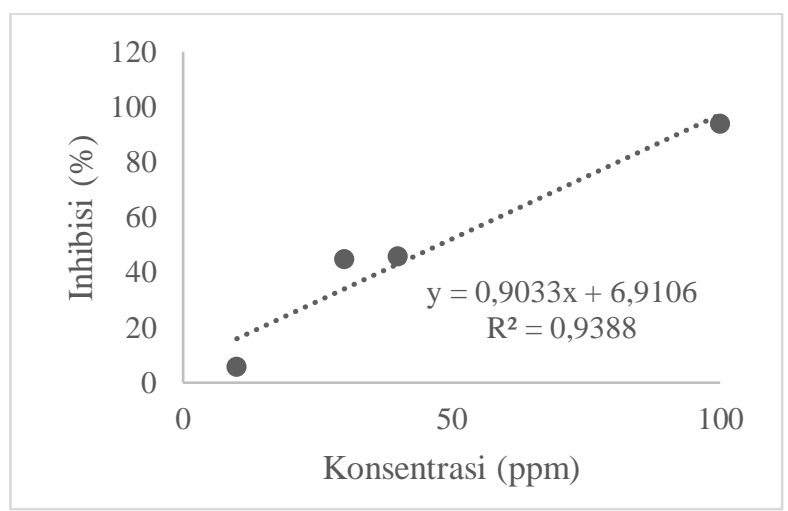

Gambar 5. Nilai Inhibisi Ekstrak Etanol Buah Rukam

Pada Gambar 4 tersebut diperoleh persamaan regresi linear $\mathrm{y}=0,9033 \mathrm{x}+6,9106$ dan nilai $\mathrm{R}^{2}=$ 0,9033 . Dari persamaan ini maka didapatkan nilai $\mathrm{IC}_{50}$ ekstrak etanol adalah 47,7022 ppm. Aktivitas peredaman radikal bebas biasanya dinyatakan sebagai presentase peredaman dari DPPH dinyatakan dengan $\mathrm{IC}_{50}$. Semakin kecil nilai $\mathrm{IC}_{50}$ maka semakin baik aktivitas antioksidannya. Hasil pengujian aktivitas antioksidan disajikan pada tabel 2. Kategori aktivitas antioksidan dinyatakan sangat kuat jika memiliki nilai $\mathrm{IC}_{50}<50 \mu \mathrm{g} / \mathrm{ml}$, kuat untuk $\mathrm{IC}_{50}$ bernilai $50-100 \mu \mathrm{g} / \mathrm{ml}$, aktivitas antioksidan sedang jika $\mathrm{IC}_{50}$ bernilai $100-500 \mu \mathrm{g} / \mathrm{ml}$, dan bersifat lemah jika nilai $\mathrm{IC}_{50}>500 \mu \mathrm{g} / \mathrm{ml}$ (Putri dan Hidajati., 2015).
Berdasarkan hasil Tabel 2 dapat dilihat bahwa ekstrak buah rukam dengan pelarut aseton memiliki nilai antioksidan yang lebih kuat dari ekstrak buah rukam dengan pelarut etanol. Aktivitas antioksidan ini terjadi dikarenakan adanya reaksi antara molekul difenil pikri hidrazil (DPPH) dengan atom hidrogen dari antioksidan yang terkandung dalam ekstrak buah rukam (Kusbandari dan Prasetyo, 2018). Menurut Putri dan Hidayati (2015) senyawa antioksidan bereaksi dengan senyawa DPPH yang menyebabkan perubahan ungu menjadi kuning.

Tabel 2. Hasil aktivitas antioksidan ekstrak buah

\begin{tabular}{cccc}
\multicolumn{4}{c}{ rukam } \\
\hline No. & $\begin{array}{c}\text { Sumber } \\
\text { Sampel }\end{array}$ & Pelarut & $\mathrm{IC}_{50}(\mathrm{ppm})$ \\
\hline 1 & $\begin{array}{c}\text { Flacourtia } \\
\text { rukam }\end{array}$ & Etanol & 47,7022 \\
& & Aseton & 33,1702 \\
\hline 2 & Flacourtia & Kloroform & 523,15 \\
& $\begin{array}{c}\text { jangomas } \\
\text { (Rahman dkk., } \\
\text { 2012) }\end{array}$ & Metanol & 1623,87 \\
& Pet. eter & 5811,35 \\
\hline 3 & $\begin{array}{c}\text { Flacourtia } \\
\text { indica } \text { Merr } \\
\text { (College dan } \\
\text { Pradesh, 2010) }\end{array}$ & Metanol & 18 \\
\hline 4 & $\begin{array}{c}\text { Flacourtia } \\
\text { inermis } \\
\text { (Alakolanga } \\
\text { dkk., 2015) }\end{array}$ & Etil asetat & 26 \\
& Metanol & 212,95 \\
& & \\
\hline
\end{tabular}

Sebelumnya telah dilakukan uji antioksidan pada tanaman yang satu genus dengan rukam yaitu pada $F$. Jangomas, $F$. Indica, $F$. Inemris (Tabel 2). Aktivitas antioksidan ekstrak aseton dan etanol buah rukam ( $F$. rukam) pada penelitian ini lebih baik dibandingkan aktivitas antioksidan ekstrak etil asetat dan metanol pada spesies $F$. inermis. Serta lebih baik juga jika dibandingan ekstrak kloroform, metanol, dan petroleum eter pada spesies $F$. jangomas. Tetapi aktivitas antioksidan pada penelitian ini tidak lebih baik jika dibandingkan ekstrak metanol dan aquades pada spesies F. indica (Rahman dkk., 2012) (College dan Pradesh, 2010) (Alakolanga dkk., 2015). Hal ini diduga pada $F$. indica banyak mengandung senyawa polar yang bersifat antioksidan 


\section{KESIMPULAN}

Pada penelitian ini diperoleh persentasi rendemen hasil ekstrak buah rukam dengan pelarut etanol adalah 12,\% dan ekstrak buah rukam dengan pelarut aseton adalah $7,5 \%$. Hasil pengujian aktivitas antioksidan menggunakan metode DPPH dengan pengukuran menggunakan spektrofotometer UV-Vis pada ekstrak buah rukam dengan pelarut aseton diperoleh $\mathrm{IC}_{50}$ $33,17025 \mathrm{ppm}$ sedangkan dengan pelarut etanol di[peroleh $\mathrm{IC}_{50} 47,7022$ ppm yang menunjukkan bahwa sifat antioksidan buah rukam ini sangat kuat.

\section{UCAPAN TERIMA KASIH}

Peneliti berterima kasih kepada Kementrian Riset, Teknologi, dan Pendidikan Tinggi Direktorat Jenderal Pembelajaran dan Kemahasiswaan yang telah memberikan bantuan dana penelitian berdasarkan SK No. 1020/B3.1/KM/2018

\section{DAFTAR PUSTAKA}

Alakolanga, A. G. A. W., Kumar, N. S., Jayasinghe, L., Fujimoto, Y., 2015, Antioxidant Property And A-Glucosidase, A-Amylase and Lipase Inhibiting Activities of Flacourtia Inermis Fruits : characterization of malic acid as an inhibitor of the enzymes J. Food Science and Technology, 52, 8383-8388.

College, S. R. N. S., Pradesh, M., 2010, In vitro Antioxidant Activity of Methanolic and Aqueous Extract of Flacourtia indica Merr Vedica College of Pharmacy, Bhopal, Madhya Pradesh, India, American-Eurasian J. Scientific Res., 5(3), 201-206.

Enggiwanto, S., Istiqomah, F., Daniati, K., Roanisca, O., Mahardika, R. G., 2018, Ekstraksi Daun Pelawan (Tristaniopsis merguensis) Sebagai Antioksidan Menggunakan Microwave Assisted Extraction (MAE), Indones. J. Pure and Applied Chem., 1(2), 50-55.

Fadiyah, I., Lestari, I., Victory, S., Mahardika, R. G., 2019, Uji Aktivitas Antioksidan Ekstrak Buah Rukam (Flacourtia rukam) menggunakan metode maserasi. Seminar Nasional Penelitian Dan Pengabdian Pada Masyarakat, 64-68.

Hemwimon, S., Pavasant, P., Shotipruk, A., 2007, Microwave-assisted extraction of antioxidative anthraquinones from roots of Morinda citrifolia. Separation and Purification Technology, 54(1), 44-50.

Julio, C., Camarena-tello, Mart, E., Garnicaromo, M. G., Saavedra-molina, A., 2018, Quantification of Phenolic Compounds and In Vitro Radical Scavenging Abilities with Leaf Extracts from Two Varieties of Psidium guajava $\mathrm{L}$. Antioxidants, 7(3), 1-12.

Kaufmann, B., Christen, P., 2002, Recent Extraction Techniques for Natural Products : Microwave-assisted Extraction and Pressurised Solvent Extraction, Phytochemcal Analysis, 113(2), 105-113.

Kusbandari, A., Prasetyo, D. Y., 2018, Determination of total phenolic content and antioxidant activity of kawa coffee leaves ethanolic extract with dpph method. Media Farmasi, 15(2), 72-80.

Mahardika, R. G., Roanisca, O., 2018, Antioxidant activity and phytochemical of extract ethyl acetat pucuk idat (Cratoxylum glaucum ). Indo. J. Chem. Res, 5(2), 481486.

Mahardika, R. G., Roanisca, O., 2019, Microwave-Assisted Extraction of Polyphenol Content from Leaves of Tristaniopsis merguensis, ASEAN J. of Chemical Engineering, 19(2), 110-119.

Pangestu, N. S., 2017, Aktivitas Antioksidan Dan Antibakteri Ekstrak Daun Jatropha gossypifolia L Abstrak Prosedur Penelitian. 1(1), 15-19.

Ragasa, C. Y., Jesus, J. De., 2014, Porphyrins and Polyprenol from Macaranga tanarius. Esearch Journal of Pharmaceutical , Biological and Chemical Sciences, 5(3), 701-708.

Ragasa, C. Y., Madeleine, J., Reyes, A., Tabin, T. J., S, M. C., Chiong, I. D., Urban, S., 2016, Chemical Constituents of Flacourtia rukam Zoli \& Moritzi Fruit. Inter. J. Pharmaceutical and Clinical Research, 8(12), 1625-1628.

Ragasa, C. Y., Ng, V. A. S., Lazaro-llanos, N., Carmen, M., Tan, S., Brklja, R., Urban, S., 2015, Monogalactosyl diacylglycerol from Caulerpara racemosa (Forsskal) J. Agardh, Der Pharma Chemica, 7(7), 194-198.

Rahman, M. M., Habib, M. R., Hasan, M. R., Islam, A. M. T., Khan, I. N., 2012, Comparative Antioxidant Potential of Different Extracts of Flacourtia Jangomas Lour Fruits, Asian J. of Pharmaceutical and 
Inas Fadiyah dkk. / Indo. J. Chem. Res., 2020, 7(2), 107-113

Clinical Res., 5(1), 2011-2013.

Rana, Ghina, S. E., Lestario, L. N., Martono, Y., 2018, Effect of Various Concentration Sugar Addition on the Color Stability of Rukem Fruit Anthocyanin Extract (Flacourtia rukam Zoll. \& Mor.), J. Aplikasi Teknologi Pangan, 7(4), 173-179.

Riza, A., Susanti, H., 2013, Penetapan Kadar Fenolik Total Ekstrak Metanol Kelopak Bunga Rosella Merah (Hibiscus Sabdariffa Linn) Dengan Variasi Tempat Tumbuh Secara Spektrofotometri, J. Ilmiah Kefarmasian, 33(3), 324-333.
Safdar, M. N., Kausar, T., Jabbar, S., Mumtaz, A., Ahad, K., Saddozai, A. A. (2017). Extraction and Quantification of Polyphenols from Kinnow (Citrus reticulate 1 .) Peel Using Ultrasound and Maceration Techniques. $J$. Food and Drug Anal., 25(3), 488-500.

Shahwar, D., Ahmad, N., Ullah, S., Raza, M. A., 2010, Antioxidant Activities of The Selected Plants from The Family Euphorbiaceae, Lauraceae, Malvaceae and Balsaminaceae, African Journal of Biotechnology, 9(7), 1086-1096. 